\title{
Challenges and Promise of a Hepatitis C Virus Vaccine
}

\author{
Andrea L. Cox \\ Department of Medicine, Division of Infectious Diseases, Johns Hopkins University, Baltimore, \\ Maryland 21205, USA \\ Correspondence: acox@jhmi.edu
}

An estimated 1.5-2 million new hepatitis C virus (HCV) infections occur globally each year. Critical to the World Health Organization's (WHO) HCV elimination strategy is an $80 \%$ reduction in incidence of HCV infections by 2030. However, even among high-income countries, few are on target to achieve the WHO's incident infection-reduction goal. A preventative vaccine could have a major impact in achieving incidence-reduction targets globally. However, barriers to HCV vaccine development are significant and include at-risk populations that are often marginalized: viral diversity, limited options for testing HCV vaccines, and an incomplete understanding of protective immune responses. In part because of those factors, testing of only one vaccine strategy has been completed in at-risk individuals as of 2019. Despite challenges, immunity against HCV protects against chronic infection in some repeated HCV exposures and an effective HCV vaccine could prevent transmission regardless of risk factors. Ultimately, prophylactic vaccines will likely be necessary to achieve global HCV elimination.

$T^{\text {his }}$ he introduction of oral, interferon-sparing, direct-acting antivirals (DAAs), which cure hepatitis C virus (HCV) with high efficacy and low toxicity, has fueled optimism for control. However, several limitations make treatment insufficient to eliminate HCV globally. The majority of $\mathrm{HCV}$-infected people remain undiagnosed because HCV infection is rarely symptomatic before the onset of advanced liver disease, and routine HCV screening is not common globally (Gravitz 2011). In addition, the cost of and practical aspects to delivering therapy globally result in a cascade of care that leaves a small subset of those diagnosed cured. HCV treatment rates have been declining globally since the peak in 2015 as the HCV-infected peo- ple easiest to access have been treated, leaving those more difficult to access without treatment (J McHutchinson and D Brainard, Gilead Sciences, pers. comm.). A very small subset of those treated develop DAA resistance, and at least some resistant HCV variants are transmissible (Franco et al. 2014). However, antiviral resistance could become more common with expansion of treatment to less compliant populations. HCV cures do not completely reverse the adverse consequences of infection in all patients, and liver disease progression and cancer occur in some patients with cirrhosis despite cure. Last, reinfection following cure in high-risk groups makes HCV elimination even more challenging. Thus, prevention of infection offers significant

Editors: Arash Grakoui, Jean-Michel Pawlotsky, and Glenn Randall

Additional Perspectives on Hepatitis C Viruses: The Story of a Scientific and Therapeutic Revolution available at www.perspectivesinmedicine.org

Copyright (C) 2020 Cold Spring Harbor Laboratory Press; all rights reserved; doi: 10.1101/cshperspect.a036947

Cite this article as Cold Spring Harb Perspect Med 2020;10:a036947 
A.L. Cox

advantages over treatment in eliminating harm from HCV.

Global control will require annual rates of cure that are consistently and significantly higher than new HCV infection rates. However, nearly $60 \%$ of surveyed countries had more infections than cures in 2016, and few countries are on target to achieve elimination of $\mathrm{HCV}$ as a public health problem by 2030, the goal set by the World Health Organization (WHO) (Hill et al. 2017; WHO 2017). In a 2018 survey of 45 high-income countries, only 11 are on target to achieve the WHO's incidence of infectionreduction goal (Razavi et al. 2019). More highincome countries met screening and treatment targets than incidence-reduction goals. Given that the gap is most significant in infection prevention, an effective vaccine would represent an important weapon in the fight for global HCV control. However, barriers to development remain, including lack of economic incentive for vaccines, limitations to HCV culture systems, viral genetic diversity, limited animal models and at-risk populations for testing vaccines, and an incomplete understanding of protective immune responses. However, both the promise and the challenges of a prophylactic $\mathrm{HCV}$ vaccination are vast (Table 1 ).

\section{ECONOMIC INCENTIVES TO SUPPORT HCV VACCINE ADVANCEMENT}

Sound market analysis dictates that development of any product is supported by having a market for that product. Although vaccines represent important tools for disease prevention and have significant social value, they frequently generate lower revenues than drugs and other health care services, and provide a less attractive opportunity for the pharmaceutical industry (Institute of Medicine Committee on the Evaluation of Vaccine Purchase Financing in the United States 2003). In addition to general disadvantages to investment in vaccines, the demographics of the target market of those at risk for $\mathrm{HCV}$ infection globally may provide further economic disincentives. In the developed world, the primary risk factor for acquiring $\mathrm{HCV}$ is injection drug use. People who inject drugs (PWID) are often not optimally engaged in health care at any stage of drug use. Reaching them soon after initiation of drug use is even more challenging but necessary because young PWID have the highest incidence of HCV infection during the first 2 years of drug use (Villano et al. 1997). An effective vaccine can only reduce the risk of $\mathrm{HCV}$ transmission if routinely pro-

Table 1. Challenges and promise of an HCV vaccine

\begin{tabular}{|c|c|}
\hline Promise & Challenges \\
\hline Vaccination prevents HCV regardless of risk factors & $\begin{array}{l}\text { Return on financial investment will be limited if } \\
\text { vaccination remains restricted to high-risk groups in } \\
\text { developed countries }\end{array}$ \\
\hline $\begin{array}{l}\text { Universal vaccination before initiation of high-risk } \\
\text { behavior provides a broad time window in which to } \\
\text { offer protection, unlike treatment as prevention }\end{array}$ & $\begin{array}{l}\text { Targeting PWID before they are infected leaves a narrow } \\
\text { time window for intervention, arguing for universal } \\
\text { vaccination }\end{array}$ \\
\hline $\begin{array}{l}\text { Protective immunity exists in chimpanzees and humans, } \\
\text { making protective vaccination possible }\end{array}$ & Correlates of protective immunity are unknown \\
\hline $\begin{array}{l}\text { Prevention of infection reduces disease burden and } \\
\text { transmission more effectively than treatment }\end{array}$ & $\begin{array}{l}\text { Culturing HCV is difficult, making live attenuated or } \\
\text { killed virus vaccines impractical } \\
\text { Testing vaccines for efficacy is difficult because of the lack } \\
\text { of a predictably high-risk population } \\
\text { HCV is a highly variable virus, making selection of } \\
\text { an antigen that elicits cross-protective responses } \\
\text { difficult }\end{array}$ \\
\hline
\end{tabular}

(HCV) hepatitis C virus, (PWID) people who inject drugs. 
vided to people before the onset of high-risk behaviors. In developing countries, contaminated injections, blood transfusions, and other exposures represent important risk factors for infection, and universal vaccination will likely be necessary in those nations to prevent HCV and reduce the burden of disease. While this will require prioritizing $\mathrm{HCV}$ prevention, modeling forecasting that viral hepatitis will kill more people globally by 2040 than human immunodeficiency virus (HIV) infection, tuberculosis, and malaria combined supports a focus on $\mathrm{HCV}$ (Foreman et al. 2018). Importantly, vaccination offers the opportunity to prevent infection regardless of risk factors, and expansion of $\mathrm{HCV}$ vaccination from the at-risk population to a universal vaccine once a vaccine has been proven safe and effective will make global control more likely, as well as make vaccine development a more attractive economic prospect.

\section{FEASIBILITY OF TRADITIONAL APPROACHES FOR HCV VACCINE DESIGN}

Generation of live attenuated and inactivated whole virus vaccines has been effective for protection against other pathogens, but neither strategy is feasible for HCV. Limitations of HCV culture systems make production of a live-attenuated or inactivated whole HCV vaccine technically very challenging (Thomas and Liang 2016). Current culture strains of $\mathrm{HCV}$ have adaptive mutations that enhance replication efficiency in vitro with unknown effects in humans. Live attenuated vaccines against other viruses have been generated by either deletion or inactivation of virulence factors and passage of virus in nonhuman primate cell lines to diminish infectivity. However, the virulence factors for $\mathrm{HCV}$ have not been defined, and HCV does not replicate at high levels in nonhuman primate cell lines. Thus, practical production aspects and the potential risk of causing disease limit the utility of live attenuated and inactivated whole $\mathrm{HCV}$ vaccines.

\section{HCV GENETIC DIVERSITY}

A major challenge for $\mathrm{HCV}$ vaccine development is the extraordinary genetic diversity of the virus, with eight known genotypes and more than 100 subtypes (Borgia et al. 2018). HCV strains from different genotypes differ on average $\sim 30 \%$ of their amino acids, whereas different subtypes within each genotype differ at an average of about $15 \%$ of their amino acids (Smith et al. 2014, 2017; Bukh 2016). In addition to diversity between genotypes and subtypes, immune selection and the error-prone polymerase of the virus generate a diverse quasispecies of related but genetically distinct viral variants within each infected individual, presenting many opportunities for selection of transmissible viral variants with resistance to $\mathrm{T}$-cell and antibody responses (Martell et al. 1992; Erickson et al. 1993; Farci et al. 1997; Forns et al. 1999; Timm et al. 2004; Cox et al. 2005; Liu et al. 2010). Given this viral diversity, vaccine induction of very broadly reactive immune responses or the generation of immune responses that target genetically conserved regions of the viral genome may be required for protection against HCV. One study showed enhanced potential for computer-generated sequences to elicit cross-reactive human $\mathrm{T}$-cell responses versus previously defined T-cell epitopes or circulating HCV variants, supporting the use of a synthetically generated sequence to elicit robust $\mathrm{CD}^{+}$T-cell responses (Burke et al. 2012). An $\mathrm{HCV}$ vaccine that encodes conserved genetic $\mathrm{HCV}$ regions generated T cells that target multiple HCV genotypes (von Delft et al. 2018). However, computational strategies to aid in $\mathrm{HCV}$ antigen design have not advanced past small animal testing.

\section{CHALLENGES IN TESTING HCV VACCINES}

Chimpanzees played a significant role in understanding the immune response to $\mathrm{HCV}$, but are no longer used in HCV research. Currently, available in vitro systems and immunocompetent small animal models permit more limited assessment of whether vaccine-induced adaptive immune responses will provide protective immunity against HCV (Thomas and Liang 2016). High DAA efficacy introduces the possibility of challenge studies in which vaccinated 
A.L. Cox

humans could be intentionally infected with HCV. Purposeful infection of healthy volunteers with HCV seems at odds with acceptable ethical standards, but controlled human infection studies have been an important contemporary research avenue for the study of other infectious disease vaccines and treatments (Bambery et al. 2016; WHO 2016) However, it is not clear how those infections would be achieved given that primary $\mathrm{HCV}$ isolates have limited ability to replicate in tissue culture and do not represent the diversity of the viral quasispecies circulating in natural infection. Direct infusion of HCV infected human plasma would require careful screening for other pathogens and might also fail to completely recapitulate natural exposure. Thus, vaccine efficacy is difficult to assess without a population at predictably high risk for $\mathrm{HCV}$ infection. Although HCV transmission occurs through iatrogenic exposure, predicting who will be at risk and vaccinating them before exposure is not feasible. Rates of HCV transmission in men having sex with men (MSM) are variable and can be high, but the highest risk MSM are HIV infected or at high risk of HIV acquisition, and testing vaccines in an HIV-infected population may underestimate immunogenicty (van de Laar et al. 2009a). In contrast, the incidence of HCV infection in HIV-uninfected PWID is predictably high at 5\%-25\% per year, identifying PWID as a vaccine test population and showing the continued need for prevention of $\mathrm{HCV}$ infection in them (Cox and Thomas 2013). However, successful identification, enrollment, and prospective monitoring of PWID before onset of acute HCV infection has been achieved in few cohorts (Cox et al. 2009; Edlin et al. 2009). These cohorts will likely remain of critical importance to vaccine testing and identification of correlates of protective immunity. Such correlates would facilitate screening of vaccine candidates in volunteers not at risk for $\mathrm{HCV}$ with the vaccines that elicit protective immune responses advancing into more difficult-to-conduct clinical trials in at-risk subjects. While the precise correlates of protective immunity against $\mathrm{HCV}$ are unknown, there is substantial evidence supporting protective immunity.

\section{EVIDENCE FOR PROTECTIVE IMMUNITY AGAINST HCV}

Spontaneous clearance of HCV infection occurs in about $25 \%$ of acutely infected individuals ( $\mathrm{Mi}$ callef et al. 2006). Chimpanzees and humans who spontaneously control HCV infection can be infected again, establishing that spontaneous clearance of primary HCV infection does not fully protect from reinfection (Farci et al. 1992; Prince 1994; Bassett et al. 2001; Major et al. 2002; Mehta et al. 2002; Nascimbeni et al. 2003; Shoukry et al. 2003; Prince et al. 2005; Micallef et al. 2007; Page et al. 2009; van de Laar et al. 2009b; Osburn et al. 2010). However, clearance of multiple infections with homologous and heterologous virus has been observed in chimpanzees and humans (Bassett et al. 2001; Prince et al. 2005; Micallef et al. 2007; Page et al. 2009; Osburn et al. 2010; Grebely et al. 2012). Furthermore, clearance occurs far more often in reinfection than in primary infection. Reinfected PWID control secondary HCV infections about $80 \%$ of the time, essentially the reverse of persistence rates observed in primary infection (Osburn et al. 2010). Adaptive immune responses would be expected to result in more rapid control of reinfection than occurs in the initial infection, and HCV reinfection is characterized by a reduced peak and duration of viremia compared to initial infection of the same person (Osburn et al. 2010; Sacks-Davis et al. 2015). Reinfection was associated with broadened cellular immune responses compared to primary infection and detectable broadly neutralizing antibodies ([bNAbs], Osburn et al. 2010). Clearance of both homologous and heterologous viral rechallenge was also associated with decreased duration and magnitude of viremia in chimpanzees compared with primary infection (Lanford et al. 2004). These studies suggest that adaptive immunity is induced in spontaneous control of $\mathrm{HCV}$ and, although not sterilizing, protects against chronic disease. While additional research aimed at understanding effective immune control of $\mathrm{HCV}$ remains important, $\mathrm{HCV}$ specific $\mathrm{CD}^{+}$helper $\mathrm{T}$ cells, $\mathrm{CD}^{+}$cytotoxic $\mathrm{T}$ cells, and antibodies are all known to play a role in protection against persistent $\mathrm{HCV}$ infection. 


\section{CELLULAR IMMUNITY TO HCV INFECTION}

Data from both human and chimpanzee studies suggests that $\mathrm{HCV}$-specific $\mathrm{CD}^{+}$and $\mathrm{CD} 8^{+}$ $T$ cells are crucial in control of primary and secondary HCV infections. Indirect evidence of T-cell control comes from genetic studies, showing associations between HCV clearance and specific class I and class II human leukocyte antigens that present peptides to $\mathrm{CD} 8^{+}$and $\mathrm{CD} 4^{+}$ T cells, respectively (Kuniholm et al. 2010; Duggal et al. 2013). The presence of a vigorous and multispecific proliferative $\mathrm{CD} 4^{+} \mathrm{T}$-cell response to $\mathrm{HCV}$ is a strong immunologic correlate of spontaneous control of acute HCV infection (Diepolder et al. 1996; Chang et al. 2001; Rehermann 2009; Schulze zur Wiesch et al. 2012). Depletion of $\mathrm{CD}^{+} \mathrm{T}$ cells before reinfection of two immune chimpanzees resulted in persistence of HCV despite functional intrahepatic memory CD8 ${ }^{+} \mathrm{T}$-cell responses. Depletion of CD8 T cells in two other immune chimpanzees resulted in prolonged viremia that was controlled only when $\mathrm{CD}^{+} \mathrm{T}$ cells were again detectable in the liver (Grakoui et al. 2003; Shoukry et al. 2003). Thus, both $\mathrm{CD}^{+}$and $\mathrm{CD} 8^{+}$memory $\mathrm{T}$ cells are important in HCV control in chimpanzees. Similarly, protection against viral persistence in recurrent HCV infection in PWID was associated with broadening of the T-cell response and the expansion of effector memory $\mathrm{T}$ cells at the peak of the T-cell response (Osburn et al. 2010; Abdel-Hakeem et al. 2014). Dominant epitope regions of HCV strains isolated from patients with persistent reinfection had sequence variations that were not recognized by preexisting memory $\mathrm{T}$ cells. Together, these studies show that memory $\mathrm{CD} 4^{+}$and $\mathrm{CD} 8^{+} \mathrm{T}$ cells play a crucial role in protective immunity upon reexposure to $\mathrm{HCV}$, and generation of effective memory $\mathrm{T}$-cell responses through vaccination is likely necessary for a successful vaccine.

\section{TRIALS OF VACCINES DESIGNED TO ELICIT CELLULAR IMMUNITY}

A variety of strategies have been used to elicit $\mathrm{HCV}$-specific $\mathrm{T}$-cell responses through vaccina- tion (Table 2). One approach is targeting relatively conserved viral proteins within the nonstructural (NS) region of the genome to induce a broad T-cell response, with and without envelope glycoproteins. NS proteins NS3, NS4, and NS5 are more conserved across HCV genotypes than the envelope glycoproteins and are dominant targets of CD $8^{+} \mathrm{T}$ cells (Ward et al. 2002). A variety of strategies have been used to introduce NS proteins in an immunogenic way, including combinations of DNA-based immunization, recombinant virus vectors, adjuvanted $\mathrm{HCV}$ proteins, virus-like particles (VLPs), hepatitis $B$ virus surface antigen-HCV recombinants, and pooled synthetic class I peptide epitopes or peptides incorporated in lysosomes (Elmowalid et al. 2007; Youn et al. 2008; Cox and Thomas 2013; Christiansen et al. 2018). Most candidate vaccines have been tested in rodents with a small subset of candidate vaccines tested in macaques and shown to elicit robust T-cell immunity (Polakos et al. 2001; Jeong et al. 2004; Rollier et al. 2005; Fattori et al. 2006; Garrone et al. 2011; Colloca et al. 2012; Lang Kuhs et al. 2012).

Because of cost and limited availability of chimpanzees, fewer vaccine candidates have been assessed for efficacy by protection of chimpanzees from HCV challenge. These vaccines include VLPs comprised of the HCV E1, E2, and core proteins, recombinant NS proteins formulated with the ISCOMATRIX adjuvant, and genetic vaccines that encoded NS proteins (Rollier et al. 2004; Folgori et al. 2006; Elmowalid et al. 2007; Youn et al. 2008; Zubkova et al. 2014). Infection outcome in vaccinated chimpanzees was highly variable, in part, because there were fewer than six vaccinated animals per study (Rollier et al. 2004; Elmowalid et al. 2007; Youn et al. 2008; Dahari et al. 2010; Zubkova et al. 2014). Genetic vaccines encoding the envelope glycoprotein induced antibodies, as well as T-cell responses, but none provided sterilizing immunity (Rollier et al. 2004; Youn et al. 2008). However, these vaccines reduced primary viremia after challenge with HCV by as much as several orders of magnitude (Rollier et al. 2004; Folgori et al. 2006; Elmowalid et al. 2007; Youn et al. 2008; Dahari et al. 2010; Zubkova et al. 2014). 
A.L. Cox

Table 2. Vaccine strategies used for HCV vaccine development

\begin{tabular}{|c|c|c|c|c|c|}
\hline \multicolumn{4}{|c|}{ Vaccine recipients for assessing immunogenicity } & \multirow{2}{*}{\multicolumn{2}{|c|}{ Immune response-induced }} \\
\hline \multirow[b]{2}{*}{$\begin{array}{l}\text { Rodents or } \\
\text { macaques }\end{array}$} & \multirow[b]{2}{*}{ Chimpanzees } & \multicolumn{2}{|c|}{ Humans } & & \\
\hline & & Not at risk for $\mathrm{HCV}$ & At risk for $\mathrm{HCV}$ & $\begin{array}{l}\text { Neutralizing } \\
\text { antibodies }\end{array}$ & T cells \\
\hline DNA-based & DNA-based & & & Not tested & Yes \\
\hline $\begin{array}{l}\text { VLPs with various } \\
\text { proteins }\end{array}$ & $\begin{array}{l}\text { VLPs with E1, E2, } \\
\text { core }\end{array}$ & $\begin{array}{l}\text { VLPs with E1, E2, } \\
\text { core }\end{array}$ & & No & Yes \\
\hline $\begin{array}{l}\text { Adjuvanted } \mathrm{HCV} \\
\text { proteins or } \\
\text { truncated E1E2 }\end{array}$ & $\begin{array}{l}\text { Adjuvanted HCV } \\
\text { proteins }\end{array}$ & $\begin{array}{l}\text { Adjuvanted HCV } \\
\text { core, adjuvanted } \\
\text { E1E2 }\end{array}$ & & Yes, for some & Yes \\
\hline $\begin{array}{l}\text { Recombinant viral } \\
\text { vectors }\end{array}$ & $\begin{array}{l}\text { Recombinant } \\
\text { viral vectors }\end{array}$ & $\begin{array}{l}\text { Recombinant viral } \\
\text { vectors }\end{array}$ & $\begin{array}{l}\text { Recombinant } \\
\text { viral vectors }\end{array}$ & Yes, for some & Yes \\
\hline Whole virus & & & & Yes & Not tested \\
\hline $\begin{array}{l}\text { Class I HCV peptide } \\
\text { epitopes }\end{array}$ & & & & No & Yes \\
\hline $\begin{array}{l}\text { Peptides } \\
\text { incorporated in } \\
\text { lysosomes }\end{array}$ & & & & No & Yes \\
\hline
\end{tabular}

(HCV) hepatitis C virus, (VLP) virus-like particle.

A meta-analysis of all the data from chimpanzee vaccine trials showed that suppression of acutephase virus replication was associated with recall of vaccine-primed $\mathrm{T}$ cells, but the levels of induced $\mathrm{T}$-cell responses did not correlate with vaccine success (Dahari et al. 2010). The analysis also found that vaccines containing only structural proteins induced significantly higher clearance rates than vaccines containing NS components. However, the vectors and antigens used, the timing of vaccination prime and boost, and the timing and identity of challenge HCV viruses used were highly varied, limiting the ability to compare these studies or conclude that inclusion of NS proteins reduces vaccine efficacy.

The majority of chimpanzee vaccine studies have shown reduced $\mathrm{HCV}$ persistence rates in vaccinees versus controls (Dahari et al. 2010). However, some studies of vaccines designed to induce $\mathrm{T}$-cell responses showed increased persistence rates. Vaccination of chimpanzees with recombinant NS3, NS4, and NS5 proteins formulated with the ISCOMATRIX adjuvant resulted in persistent $\mathrm{HCV}$ infection on rechallenge in five of five vaccinated animals, despite the appearance of $\mathrm{HCV}$ multispecific $\mathrm{CD} 4^{+}$and $\mathrm{CD} 8^{+} \mathrm{T}$-cell responses in the liver before exper- imental challenge and infection (Houghton 2011). A second vaccine study in which naive chimpanzees were immunized with DNA plasmids expressing the core-E1E2 and NS3 for priming and with recombinant modified vaccinia ankara (MVA)-expressing core-E1E2 and NS3 gene sequences as a boost induced HCVspecific antibody and $\mathrm{T}$-cell responses (Rollier et al. 2007). Despite these immune responses, vaccinated animals showed a higher rate of persistence than control animals. That HCV vaccine failures have occurred in the presence of $\mathrm{T}$ cell responses indicates that trials should proceed with caution and include detailed immune response analysis aimed at defining responses associated with control. In addition to the limitations of prior studies as a result of the small number of chimpanzees tested, the diversity of the vaccines tested, and the different methods of immune response analysis, it is also unclear whether the results from nonhuman primates can be translated to humans. More detailed phenotypic and functional analyses performed on existing and future trial specimens will be needed to gain insight into factors that determine whether a vaccine will reduce the rate of persistent infection in humans. 
Human Trials of HCV Vaccines Designed to Elicit T-Cell Responses

Two vaccines designed to prevent infection solely by eliciting T-cell immunity have advanced to immunogenicity trials in human volunteers not at risk for $\mathrm{HCV}$ infection. A prototype vaccine with the HCV core protein and ISCOMATRIX adjuvant was assessed for its ability to induce $\mathrm{T}$-cell responses in healthy individuals not at risk for HCV infection (Drane et al. 2009). Although the vaccine was generally well tolerated, $\mathrm{CD}^{+} \mathrm{T}$-cell responses were only detected in two of the eight participants receiving the highest dose, and the vaccine was thus not advanced into an at-risk population. A second vaccine composed of a replication-defective chimpanzee adenovirus (ChAd) vector encoding NS3, NS4, and NS5 proteins elicited robust $\mathrm{T}$-cell responses in healthy volunteers, and is the foundation of the only HCV vaccine trial completed in at-risk human subjects (Swadling et al. 2014).

Replication-defective adenovirus vectors have long been studied as a means to introduce antigens from other pathogens. Human adenovirus serotype 5 (Ad5) elicits robust and sustained cellular immunity in humans. However, most humans have neutralizing antibodies (NAbs) to Ad5 because of natural exposure, which can reduce immune responses to the antigens carried in Ad5-based vaccines. Replication-defective adenoviral vectors based on serotype 6 (subgroup C) and serotype 24 (subgroup D) have low seroprevalence in humans, reducing immunologic cross-reactivity (Colloca et al. 2012). A segment of DNA coding for NS3-5 of the HCV genotype $1 \mathrm{~b}$ was delivered by Ad6 followed by Ad24 and, finally, by electroporated plasmid DNA in chimpanzees (Folgori et al. 2006). Following HCV rechallenge with HCV genotype la virus, all five vaccinated chimpanzees showed significantly lower alanine amino transferase (ALT) levels and blunted peak of viremia with the average peak more than 100 times lower than in the control group, kinetics similar to those observed in PWID with successful control of repeated HCV exposure (Osburn et al. 2010). Four of the five vaccinated chimpanzees cleared the virus with a significantly shorter duration of viremia versus the control group, whereas one vaccinated chimpanzee maintained low levels of HCV RNA for the duration of the study. A follow-up study revealed that after challenge, vaccinated chimpanzees showed early expansion of $\mathrm{CD}^{+} \mathrm{T}$ cells with higher expression of the memory precursor molecule CD127, lower levels of the inhibitory molecule PD-1, and enhanced effector functions when compared with primary $\mathrm{T}$ cells from the mock-vaccinated controls that developed persistent infections (Park et al. 2012). Analogous to this, early expansion of $\mathrm{CD} 127^{+} \mathrm{HCV}$-specific T cells with high functionality was shown in chimpanzees that spontaneously control acute HCV infection (Shin et al. 2013).

Replication-defective vectors generated from a subset of novel ChAd serotypes were then screened to identify those not neutralized by human sera and able to grow in human cell lines (Colloca et al. 2012). Of these, ChAd3 expressing the NS region from $\mathrm{HCV}$ was found to induce long-lasting $\mathrm{T}$ - and B-cell memory responses in mice and macaques. Ad6 and ChAd3 were used as vectors to express NS proteins from $\mathrm{HCV}$ genotype $1 \mathrm{~b}$ and tested as vaccines in a safety and immunogenicity phase 1 clinical trial in healthy volunteers not at risk for $\mathrm{HCV}$ infection (Barnes et al. 2012). ChAd3-NS was well tolerated and highly immunogenic, with intracellular cytokine staining showing that ChAd3-NSmut primed a large number of polyfunctional $\mathrm{CD}^{+} \mathrm{T}$ cells. Antigen-specific polyfunctional $\mathrm{CD}^{+}{ }^{+} \mathrm{T}$ cells were detected at a lower frequency. Memory $\mathrm{CD}^{+} \mathrm{T}$ cells that expressed CD127, but not PD-1, were sustained in circulation. Although more robust recognition of $\mathrm{HCV}$ genotype $1 \mathrm{~b}$ peptides was observed, T cells recognized genotype 1a and 3a peptide pools, suggesting potential cross-genotypic protection. Central and effector memory T-cell pools retained polyfunctionality and proliferative capacity for at least a year after boosting. Boosting was subsequently found to be more robust with modified MVA than with heterologous adenovirus (Swadling et al. 2014) so the vaccine was advanced to $\mathrm{HCV}$ at-risk subjects with $\mathrm{ChAd} 3$ prime and MVA boost, both expressing NS3-5. 
A.L. Cox

The ChAd3-NS prime and MVA-NS boost strategy is now being analyzed for efficacy following completion of a staged phase I/II study (see ClinicalTrials.gov, NCT01436357). The primary end point of this study is to prevent $\mathrm{HCV}$ persistence in $\mathrm{HCV}$-naive populations of PWID at high risk for infection with immunogenicity and incidence also being assessed. This trial shows the feasibility of conducting HCV vaccine trials in PWID with full results to be released in 2019.

\section{HUMORAL IMMUNITY TO HCV INFECTION}

Many licensed prophylactic vaccines against other viral infections induce neutralizing or binding antibody titers that correlate with protection. However, the role on antibodies in $\mathrm{HCV}$ infection is defined less clearly. The HCV envelope genes (E1E2) are extremely diverse, and rapid evolution of envelope proteins permits escape from the humoral immune response in persistent infection (Dowd et al. 2009). Several recent studies have shown that antibody resistance can arise from mutations either within or distant from antibody-binding epitopes, providing multiple viral mechanisms of immune escape (Carlsen et al. 2014; Bailey et al. 2015; El-Diwany et al. 2017). However, both humans and animal models of HCV infection show that NAbs can also protect. Clearance of HCV infection is associated with the early development of serum antibodies capable of blocking infection by multiple heterologous HCV strains (Logvinoff et al. 2004; Pestka et al. 2007; Osburn et al. 2014). The appearance later in infection of NAbs has also been associated temporally with spontaneous HCV clearance (Raghuraman et al. 2012). Clearance of reinfection was associated with rapid induction of bNAbs, as well as broadening of T-cell responses (Osburn et al. 2010). Although envelope sequence evolution permits humoral escape, acquisition of resistance to bNAbs by some autologous strains has also been accompanied by progressive loss of envelope protein function and temporally associated with HCV clearance (Kinchen et al. 2018). Thus, bNAbs can mediate clearance of human $\mathrm{HCV}$ infection by driving escaped viruses to an unfit state, as well as by neutralizing infecting strains. Combinations of human NAbs targeting multiple epitopes can display complementary neutralizing breadth and, in some cases, neutralizing synergy (Mankowski et al. 2018). Notably, bNAbs displaying low levels of somatic hypermutation similar to those stimulated by vaccination against other viruses have been isolated from the B cells of individuals who cleared HCV infection without treatment, suggesting that vaccine induction of bNAbs against HCV may be feasible (Scherer et al. 2014; Wang et al. 2015; Merat et al. 2016; Bailey et al. 2017).

Antibodies can also provide protection against HCV in animal challenge models. Infusion of immunoglobulin isolated from a chronically infected human before challenge with homologous virus prevented infection of most human liver chimeric mice and infusion before chimpanzee challenge prevented infection with homologous but not heterologous HCV strains (Vanwolleghem et al. 2008; Meuleman et al. 2011; Bukh et al. 2015). Infusion of bNAbs before challenge with heterologous virus could partially or fully prevent infection in humanized mice (Law et al. 2008; Giang et al. 2012; Keck et al. 2016) and chimpanzees (Morin et al 2012), and combinations of bNAbs also abrogated established HCV infection in human liver chimeric mice (de Jong et al. 2014). Together, these studies show that strain-specific NAbs will not be sufficient, and induction of bNAbs is likely necessary to prevent infection by diverse, heterologous HCV strains.

\section{TRIALS OF VACCINES DESIGNED TO INDUCE HUMORAL IMMUNITY}

Strategies developed to induce antibodies against HCV have included protein-based, DNA-based, VLP-based, pox virus-based, and whole virus-based vaccines (Table 2 ). A vaccine composed of recombinant full-length E1E2 protein from a single genotype 1a HCV strain with oil-in-water adjuvant has been tested in rodents, nonhuman primates, and humans. This vaccine induced heterologous neutralizing activity in guinea pigs (Stamataki et al. 2007), and was protective against homologous $\mathrm{HCV}$ challenge in 
chimpanzees (Choo et al. 1994). Although it did not prevent infection, it reduced rates of persistence in chimpanzees after challenge with a neutralization-sensitive heterologous virus (Houghton 2011). However, postvaccination bNAb titers in a phase 1a human trial were detectable in only three of 16 vaccinees despite induction of robust $\mathrm{CD} 4^{+} \mathrm{T}$-cell proliferation in response to recombinant E1E2, suggesting that further optimization of the vaccine antigen or adjuvant may be needed to maximize bNAb induction (Frey et al. 2010; Law et al. 2013).

\section{Vaccine Other than Recombinant Full-Length E1E2 Protein}

Other vaccines designed to induce bNAbs, including those expressing envelope proteins in vivo using DNA vaccination, using DNA priming followed by recombinant MVA boost, or expressing envelope proteins on VLPs have all induced relatively disappointing humoral responses in chimpanzees (for review, see Liang 2013; Bukh 2016). In one study, two chimpanzees vaccinated with DNA designed to express cell-surface E2 protein developed low levels of E2-specific antibodies (Forns et al. 2000). A DNA prime, MVA boost vaccine expressing core, E1, E2, and NS3 proteins failed to induce detectable NAb titers in chimpanzees (Rollier et al. 2007). In another study, chimpanzees vaccinated with VLPs composed of HCV core, E1, and $\mathrm{E} 2$ proteins, which induced strong envelopespecific antibody responses in baboons (Jeong et al. 2004), developed no or barely detectable antibody responses despite having robust $\mathrm{T}$ cell responses against core and E1E2 (Elmowalid et al. 2007). Among varied explanations for the weak NAb responses observed in chimpanzees, HCV-infected chimpanzees generally mount less vigorous antienvelope antibody responses than humans upon infection, highlighting a limitation of chimpanzees as a model (Bassett et al. 1998a,b; Lanford et al. 2001).

As the efficiency of production of chimeric replication-competent cell culture viruses (HCVcc) has improved, use of whole inactivated virus has been explored as a vaccine strategy. In one study, vaccination of mice with inactivated
J6/JFH-1 HCVcc stimulated NAb against homologous and two heterologous HCV strains, and infusion of purified immunoglobulin from vaccinated mice prevented homologous viral infection of human liver chimeric mice (Akazawa et al. 2013). Other groups have developed multivalent VLPs or purified recombinant E1E2 protein vaccines expressing envelope genes from multiple genotypes as a means to generate bNAbs. Both induced cross-reactive antibodies in mice, and the multivalent E1E2 protein vaccine induced NAbs against one homologous and one heterologous HCV strain (Christiansen et al. 2018; Krapchev et al. 2018). Truncated protein antigens and rationally designed peptide antigens are also at early stages of development. Studies showing that hypervariable region 1 (HVR1) may block conserved bNAb epitopes (Prentoe et al. 2011) prompted testing of an E2 vaccine antigen with three variable regions deleted (Vietheer et al. 2017). This vaccine induced moderately high titers of bNAbs (Vietheer et al. 2017), but another study showed that full-length E1E2 and a variant with truncated HVR1 induced equivalent titers of NAbs against heterologous HCV strains in guinea pigs, suggesting that truncation of HVR1 may not be necessary (Law et al. 2018). A molecular scaffold presenting an epitope targeted by a potent bNAb induced modest antibody responses in vaccinated mice (Pierce et al. 2017). Overall, more research is needed to identify ideal vaccine antigens and platforms for immunization to induce potent bNAbs. Additionally, it is unclear that anti$\mathrm{HCV}$ antibody responses induced in rodents or nonhuman primates are predictive of vaccine responses in humans, highlighting the need for identification of correlates of protective immunity and future human trials.

\section{POPULATIONS TO BENEFIT FROM VACCINATION}

Those at higher than average risk of HCV infection include PWID, MSM, health care workers with frequent exposure to blood and bodily fluids, infants born to HCV-infected mothers, and those living in countries with high HCV incidence. In addition, restoration of immunity fol- 
A.L. Cox

lowing treatment is insufficient to prevent $\mathrm{HCV}$ reinfection in those at ongoing risk of infection. Reinfection rates vary, but are high when those at greatest risk of HCV exposure and transmission are treated, in part, as a means to interrupt transmission (Martin et al. 2013; Pineda et al. 2015; Midgard et al. 2016; Martinello et al. 2017). A recent study in PWID treated while still actively injecting showed 6-month and 18-month reinfection rates of 12.6 and 17.1 per 100 person-years, respectively (Schulkind et al. 2019). Thus, those previously treated and at ongoing risk of infection should be added to the list of those who would be expected to benefit from a preventative $\mathrm{HCV}$ vaccine. The impact of a prophylactic HCV vaccine has been modeled, including models that vary delivery strategy and levels of vaccine efficacy (Hahn et al. 2009; Scott et al. 2015; Stone et al. 2016). Using these models, high vaccination rates of high-risk seronegative PWID using a vaccine with as little as 30\% efficacy had significant impact. The most effective vaccines might prevent infection, but vaccines that prevent persistence of infection could decrease HCV morbidity and mortality without reducing incidence. The feasibility of testing vaccines that could reduce rates of chronic $\mathrm{HCV}$ infection or HCV RNA levels rather than incidence has been studied, and vaccines reducing viremia during the early acute phase of infection also have potential to reduce $\mathrm{HCV}$ transmission by lowering the residual infectious virus titers in injecting equipment (White et al. 2014; Major et al. 2018). Thus, setting goals for decreased persistence rates or population $\mathrm{HCV}$ RNA levels following vaccination may be reasonable given the potential to impact disease sequelae and transmission.

\section{CONCLUDING REMARKS}

There remain some significant deficits in our tool chest in the quest for an HCV vaccine. Elucidating the mechanisms through which antigen-specific immune cell populations mediate long-term protection will continue to be an important goal. Going forward, successful control of HCV infection will most likely require a combination of mass global screening to identify those with infection, treatment of those infected, and prevention and harm-reduction strategies for those who are uninfected and at risk. Although there remain challenges, a prophylactic $\mathrm{HCV}$ vaccine is likely to be required as part of a successful strategy for global control.

\section{ACKNOWLEDGMENTS}

A.L.C. is funded by the National Institute of Allergy and Infectious Diseases (NIAID U19AI088791).

\section{REFERENCES}

Abdel-Hakeem MS, Bédard N, Murphy D, Bruneau J, Shoukry NH. 2014. Signatures of protective memory immune responses during hepatitis $\mathrm{C}$ virus reinfection. Gastroenterology 147: 870-881.e8. doi:10.1053/j.gastro.2014 .07 .005

Akazawa D, Moriyama M, Yokokawa H, Omi N, Watanabe N, Date T, Morikawa K, Aizaki H, Ishii K, Kato T, et al. 2013. Neutralizing antibodies induced by cell culture-derived hepatitis $\mathrm{C}$ virus protect against infection in mice. Gastroenterology 145: 447-455.e4. doi:10.1053/j.gastro 2013.05.007

Bailey JR, Wasilewski LN, Snider AE, El-Diwany R, Osburn WO, Keck Z, Foung SK, Ray SC. 2015. Naturally selected hepatitis $\mathrm{C}$ virus polymorphisms confer broad neutralizing antibody resistance. J Clin Invest 125: 437-447. doi:10 $.1172 /$ JCI78794

Bailey JR, Flyak AI, Cohen VJ, Li H, Wasilewski LN, Snider AE, Wang S, Learn GH, Kose N, Loerinc L, et al. 2017. Broadly neutralizing antibodies with few somatic mutations and hepatitis C virus clearance. JCI insight 2: 92872 doi:10.1172/jci.insight.92872

Bambery B, Selgelid M, Weijer C, Savulescu J, Andrew P. 2016. Ethical criteria for human challenge studies in infectious diseases. Public Health Ethics 9: 92-103. doi:10 .1093/phe/phv026

Barnes E, Folgori A, Capone S, Swadling L, Aston S, Kurioka A, Meyer J, Huddart R, Smith K, Townsend R, et al. 2012. Novel adenovirus-based vaccines induce broad and sustained T cell responses to HCV in man. Sci Transl Med 4: 115ra1. doi:10.1126/scitranslmed.3003155

Bassett SE, Brasky KM, Lanford RE. 1998a. Analysis of hepatitis $\mathrm{C}$ virus-inoculated chimpanzees reveals unexpected clinical profiles. J Virol 72: 2589-2599.

Bassett SE, Thomas DL, Brasky KM, Lanford RE. 1998b. Viral persistence, antibody to E1 and E2 and HVR-1 sequence stability in hepatitis $\mathrm{C}$ virus-inoculated chimpanzees. J Virol 73: 1118-1126.

Bassett SE, Guerra B, Brasky K, Miskovsky E, Houghton M, Klimpel GR, Lanford RE. 2001. Protective immune response to hepatitis $\mathrm{C}$ virus in chimpanzees rechallenged following clearance of primary infection. Hepatology 33: 1479-1487. doi:10.1053/jhep.2001.24371 
Borgia SM, Hedskog C, Parhy B, Hyland RH, Stamm LM, Brainard DM, Subramanian MG, McHutchison JG, Mo H, Svarovskaia E, et al. 2018. Identification of a novel hepatitis $\mathrm{C}$ virus genotype from Punjab, India: expanding classification of hepatitis $\mathrm{C}$ virus into 8 genotypes. J Infect Dis 218: 1722-1729. doi:10.1093/infdis/jiy401

Bukh J. 2016. The history of hepatitis C virus (HCV): basic research reveals unique features in phylogeny, evolution and the viral life cycle with new perspectives for epidemic control. J Hepatol 65: S2-S21. doi:10.1016/j.jhep.2016.07 .035

Bukh J, Engle RE, Faulk K, Wang RY, Farci P, Alter HJ, Purcell RH. 2015. Immunoglobulin with high-titer in vitro cross-neutralizing hepatitis $\mathrm{C}$ virus antibodies passively protects chimpanzees from homologous, but not heterologous, challenge. J Virol 89: 9128-9132. doi:10 .1128/JVI.01194-15

Burke KP, Munshaw S, Osburn WO, Levine J, Liu L, Sidney J, Sette A, Ray SC, Cox AL. 2012. Immunogenicity and cross-reactivity of a representative ancestral sequence in hepatitis C virus infection. J Immunol 188: 5177-5188. doi:10.4049/jimmunol.1103008

Carlsen TH, Pedersen J, Prentoe JC, Giang E, Keck ZY, Mikkelsen LS, Law M, Foung SK, Bukh J. 2014. Breadth of neutralization and synergy of clinically relevant human monoclonal antibodies against HCV genotypes 1a, 1b, 2a, 2b, 2c, and 3a. Hepatology 60: 1551-1562. doi:10.1002/ hep. 27298

Chang KM, Thimme R, Melpolder JJ, Oldach D, Pemberton J, Moorhead-Loudis J, McHutchison JG, Alter HJ, Chisari FV. 2001. Differential CD4 ${ }^{+}$and $\mathrm{CD} 8^{+} \mathrm{T}$-cell responsiveness in hepatitis C virus infection. Hepatology 33: 267276. doi:10.1053/jhep.2001.21162

Choo QL, Kuo G, Ralston R, Weiner A, Chien D, van Nest G, Han J, Berger K, Thudium K, Kuo C. 1994. Vaccination of chimpanzees against infection by the hepatitis $\mathrm{C}$ virus. Proc Natl Acad Sci 91: 1294-1298. doi:10.1073/pnas.91 .4 .1294

Christiansen D, Earnest-Silveira L, Chua B, Meuleman P, Boo I, Grubor-Bauk B, Jackson DC, Keck ZY, Foung SKH, Drummer HE, et al. 2018. Immunological responses following administration of a genotype $1 \mathrm{a} / 1 \mathrm{~b} / 2 / 3 \mathrm{a}$ quadrivalent HCV VLP vaccine. Sci Rep 8: 6483. doi:10 $.1038 / \mathrm{s} 41598-018-24762-9$

Colloca S, Barnes E, Folgori A, Ammendola V, Capone S, Cirillo A, Siani L, Naddeo M, Grazioli F, Esposito ML, et al. 2012. Vaccine vectors derived from a large collection of simian adenoviruses induce potent cellular immunity across multiple species. Sci Transl Med 4: 115ra2. doi:10 $.1126 /$ scitranslmed.3002925

Cox AL, Thomas DL. 2013. Hepatitis C virus vaccines among people who inject drugs. Clin Infect Dis 57(Suppl 2): S46-S50. doi:10.1093/cid/cit329

Cox AL, Mosbruger T, Mao Q, Liu Z, Wang XH, Yang HC, Sidney J, Sette A, Pardoll D, Thomas DL, et al. 2005. Cellular immune selection with hepatitis $\mathrm{C}$ virus persistence in humans. J Exp Med 201: 1741-1752. doi:10.1084/ jem.20050121

Cox AL, Page K, Bruneau J, Shoukry NH, Lauer GM, Kim AY, Rosen HR, Radziewicz H, Grakoui A, Fierer DS, et al. 2009. Rare birds in North America: acute hepatitis C cohorts. Gastroenterology 136: 26-31. doi:10.1053/j gastro.2008.11.049

Dahari H, Feinstone SM, Major ME. 2010. Meta-analysis of hepatitis $\mathrm{C}$ virus vaccine efficacy in chimpanzees indicates an importance for structural proteins. Gastroenterology 139: 965-974. doi:10.1053/j.gastro.2010.05.077

de Jong YP, Dorner M, Mommersteeg MC, Xiao JW, Balazs $A B$, Robbins JB, Winer BY, Gerges S, Vega K, Labitt RN, et al. 2014. Broadly neutralizing antibodies abrogate established hepatitis C virus infection. Sci Transl Med 6: 254ra129. doi:10.1126/scitranslmed.3009512

Diepolder HM, Zachoval R, Hoffmann RM, Jung MC, Gerlach T, Pape GR. 1996. The role of hepatitis C virus specific $\mathrm{CD} 4^{+} \mathrm{T}$ lymphocytes in acute and chronic hepatitis C. J Mol Med 74: 583-588. doi:10.1007/s001090050062

Dowd KA, Netski DM, Wang XH, Cox AL, Ray SC. 2009. Selection pressure from neutralizing antibodies drives sequence evolution during acute infection with hepatitis $\mathrm{C}$ virus. Gastroenterology 136: 2377-2386. doi:10.1053/j gastro.2009.02.080

Drane D, Maraskovsky E, Gibson R, Mitchell S, Barnden M, Moskwa A, Shaw D, Gervase B, Coates S, Houghton M, et al. 2009. Priming of $\mathrm{CD}^{+}$and $\mathrm{CD}^{+}{ }^{+} \mathrm{T}$ cell responses using a HCV core ISCOMATRIX vaccine: a phase I study in healthy volunteers. Hum Vaccin 5: 151-157. doi:10 $.4161 /$ hv.5.3.6614

Duggal P, Thio CL, Wojcik GL, Goedert JJ, Mangia A, Latanich R, Kim AY, Lauer GM, Chung RT, Peters MG, et al. 2013. Genome-wide association study of spontaneous resolution of hepatitis $\mathrm{C}$ virus infection: data from multiple cohorts. Ann Intern Med 158: 235-245. doi:10.7326 0003-4819-158-4-201302190-00003

Edlin BR, Shu MA, Winkelstein E, Des Jarlais DC, Busch MP, Rehermann B, O’Brien TR, Talal AH, Tobler LH, Zeremski M, et al. 2009. More rare birds, and the occasional swan. Gastroenterology 136: 2412-2414. doi:10 1053/j.gastro.2009.04.040

El-Diwany R, Cohen VJ, Mankowski MC, Wasilewski LN, Brady JK, Snider AE, Osburn WO, Murrell B, Ray SC, Bailey JR. 2017. Extra-epitopic hepatitis $C$ virus polymorphisms confer resistance to broadly neutralizing antibodies by modulating binding to scavenger receptor B1. PLoS Pathog 13: e1006235. doi:10.1371/journal.ppat.1006235

Elmowalid GA, Qiao M, Jeong SH, Borg BB, Baumert TF, Sapp RK, Hu Z, Murthy K, Liang TJ. 2007. Immunization with hepatitis $\mathrm{C}$ virus-like particles results in control of hepatitis C virus infection in chimpanzees. Proc Natl Acad Sci 104: 8427-8432. doi:10.1073/pnas.0702162104

Erickson AL, Houghton M, Choo QL, Weiner AJ, Ralston R, Muchmore E, Walker CM. 1993. Hepatitis C virus-specific CTL responses in the liver of chimpanzees with acute and chronic hepatitis C. J Immunol 151: 4189-4199.

Farci P, Alter HJ, Govindarajan S, Wong DC, Engle R, Lesniewski RR, Mushahwar IK, Desai SM, Miller RH, Ogata $\mathrm{N}$, et al. 1992. Lack of protective immunity against reinfection with hepatitis C virus. Science 258: 135-140. doi:10.1126/science.1279801

Farci P, Bukh J, Purcell RH. 1997. The quasispecies of hepatitis $\mathrm{C}$ virus and the host immune response. Springer Semin Immunopathol 19: 5-26. doi:10.1007/BF00945022

Fattori E, Zampaglione I, Arcuri M, Meola A, Ercole BB, Cirillo A, Folgori A, Bett A, Cappelletti M, Sporeno E, 
A.L. Cox

et al. 2006. Efficient immunization of rhesus macaques with an HCV candidate vaccine by heterologous primingboosting with novel adenoviral vectors based on different serotypes. Gene Ther 13: 1088-1096. doi:10.1038/sj.gt .3302754

Folgori A, Capone S, Ruggeri L, Meola A, Sporeno E, Ercole BB, Pezzanera M, Tafi R, Arcuri M, Fattori E, et al. 2006. A T-cell HCV vaccine eliciting effective immunity against heterologous virus challenge in chimpanzees. Nat Med 12: $190-197$. doi:10.1038/nm 1353

Foreman KJ, Marquez N, Dolgert A, et al. 2018. Forecasting life expectancy, years of life lost, and all-cause and causespecific mortality for 250 causes of death: reference and alternative scenarios for 2016-40 for 195 countries and territories. Lancet 392: 2052-2090. doi:10.1016/S01406736(18)31694-5

Forns X, Purcell RH, Bukh J. 1999. Quasispecies in viral persistence and pathogenesis of hepatitis $\mathrm{C}$ virus. Trends Microbiol 7: 402-410. doi:10.1016/S0966-842X (99)01590-5

Forns X, Payette PJ, Ma X, Satterfield W, Eder G, Mushahwar IK, Govindarajan S, Davis HL, Emerson SU, Purcell RH, et al. 2000. Vaccination of chimpanzees with plasmid DNA encoding the hepatitis $\mathrm{C}$ virus (HCV) envelope E2 protein modified the infection after challenge with homologous monoclonal HCV. Hepatology 32: 618625. doi:10.1053/jhep.2000.9877

Franco S, Tural C, Nevot M, Moltó J, Rockstroh JK, Clotet B, Martinez MA. 2014. Detection of a sexually transmitted hepatitis $\mathrm{C}$ virus protease inhibitor-resistance variant in a human immunodeficiency virus-infected homosexual man. Gastroenterology 147: 599-601.e1. doi:10.1053/j .gastro.2014.05.010

Frey SE, Houghton M, Coates S, Abrignani S, Chien D, Rosa D, Pileri P, Ray R, Di Bisceglie AM, Rinella P, et al. 2010. Safety and immunogenicity of HCV E1E2 vaccine adjuvanted with MF59 administered to healthy adults. Vaccine 28: 6367-6373. doi:10.1016/j.vaccine.2010.06.084

Garrone P, Fluckiger AC, Mangeot PE, Gauthier E, Dupeyrot-Lacas P, Mancip J, Cangialosi A, Du CI, LeGrand R, Mangeot I, et al. 2011. A prime-boost strategy using virus-like particles pseudotyped for HCV proteins triggers broadly neutralizing antibodies in macaques. Sci Transl Med 3: 94ra71. doi:10.1126/scitranslmed.3002330

Giang E, Dorner M, Prentoe JC, Dreux M, Evans MJ, Bukh J, Rice CM, Ploss A, Burton DR, Law M. 2012. Human broadly neutralizing antibodies to the envelope glycoprotein complex of hepatitis C virus. Proc Natl Acad Sci 109: 6205-6210. doi:10.1073/pnas.1114927109

Grakoui A, Shoukry NH, Woollard DJ, Han JH, Hanson HL, Ghrayeb J, Murthy KK, Rice CM, Walker CM. 2003. HCV persistence and immune evasion in the absence of memory T cell help. Science 302: 659-662. doi:10.1126/science .1088774

Gravitz L. 2011. Introduction: a smouldering public-health crisis. Nature 474: S2-S4. doi:10.1038/474S2a

Grebely J, Prins M, Hellard M, Cox AL, Osburn WO, Lauer G, Page K, Lloyd AR, Dore GJ. 2012. Hepatitis C virus clearance, reinfection, and persistence, with insights from studies of injecting drug users: towards a vaccine. Lancet Infect Dis 12: 408-414. doi:10.1016/S1473-3099(12) 70010-5
Hahn JA, Wylie D, Dill J, Sanchez MS, Lloyd-Smith JO, Page-Shafer K, Getz WM. 2009. Potential impact of vaccination on the hepatitis $C$ virus epidemic in injection drug users. Epidemics 1: 47-57. doi:10.1016/j.epidem .2008 .10 .002

Hill AM, Nath S, Simmons B. 2017. The road to elimination of hepatitis C: analysis of cures versus new infections in 91 countries. J Virus Erad 3: 117-123.

Houghton M. 2011. Prospects for prophylactic and therapeutic vaccines against the hepatitis $C$ viruses. Immunol Rev 239: 99-108. doi:10.1111/j.1600-065X.2010.00977.x

Institute of Medicine Committee on the Evaluation of Vaccine Purchase Financing in the United States. 2003. Financing vaccines in the 21st century: assuring access and availability. National Academies Press, Washington, DC.

Jeong SH, Qiao M, Nascimbeni M, Hu Z, Rehermann B, Murthy K, Liang TJ. 2004. Immunization with hepatitis $\mathrm{C}$ virus-like particles induces humoral and cellular immune responses in nonhuman primates. J Virol 78: 69957003. doi:10.1128/JVI.78.13.6995-7003.2004

Keck ZY, Wang Y, Lau P, Lund G, Rangarajan S, Fauvelle C, Liao GC, Holtsberg FW, Warfield KL, Aman MJ, et al. 2016. Affinity maturation of a broadly neutralizing human monoclonal antibody that prevents acute hepatitis C virus infection in mice. Hepatology 64: 1922-1933. doi:10 $.1002 /$ hep. 28850

Kinchen VJ, Zahid MN, Flyak AI, Soliman MG, Learn GH, Wang S, Davidson E, Doranz BJ, Ray SC, Cox AL, et al. 2018. Broadly neutralizing antibody mediated clearance of human hepatitis C virus infection. Cell Host Microbe 24: 717-730.e5. doi:10.1016/j.chom.2018.10.012

Krapchev VB, Rychlowska M, Chmielewska A, Zimmer K, Patel AH, Bienkowska-Szewczyk K. 2018. Recombinant Flag-tagged E1E2 glycoproteins from three hepatitis C virus genotypes are biologically functional and elicit cross-reactive neutralizing antibodies in mice. Virology 519: 33-41. doi:10.1016/j.virol.2018.03.026

Kuniholm MH, Kovacs A, Gao X, Xue X, Marti D, Thio CL, Peters MG, Terrault NA, Greenblatt RM, Goedert JJ, et al. 2010. Specific human leukocyte antigen class I and II alleles associated with hepatitis $\mathrm{C}$ virus viremia. Hepatology 51: 1514-1522. doi:10.1002/hep.23515

Lanford RE, Bigger C, Bassett S, Klimpel G. 2001. The chimpanzee model of hepatitis $C$ virus infections. ILAR J 42: 117-126. doi:10.1093/ilar.42.2.117

Lanford RE, Guerra B, Chavez D, Bigger C, Brasky KM, Wang XH, Ray SC, Thomas DL. 2004. Cross-genotype immunity to hepatitis C virus. J Virol 78: 1575-1581. doi:10.1128/JVI.78.3.1575-1581.2004

Lang Kuhs KA, Ginsberg AA, Yan J, Wiseman RW, Khan AS, Sardesai NY, O'Connor DH, Weiner DB. 2012. Hepatitis $\mathrm{C}$ virus NS3/NS4A DNA vaccine induces multiepitope $\mathrm{T}$ cell responses in rhesus macaques mimicking human immune responses [corrected]. Mol Ther 20: 669678. doi:10.1038/mt.2011.188

Law M, Maruyama T, Lewis J, Giang E, Tarr AW, Stamataki Z, Gastaminza P, Chisari FV, Jones IM, Fox RI, et al. 2008. Broadly neutralizing antibodies protect against hepatitis $\mathrm{C}$ virus quasispecies challenge. Nat Med 14: 25-27. doi:10 $.1038 / \mathrm{nm} 1698$

Law JL, Chen C, Wong J, Hockman D, Santer DM, Frey SE, Belshe RB, Wakita T, Bukh J, Jones CT, et al. 2013. A 
hepatitis $\mathrm{C}$ virus (HCV) vaccine comprising envelope glycoproteins gpE1/gpE2 derived from a single isolate elicits broad cross-genotype neutralizing antibodies in humans. PLoS ONE 8: e59776. doi:10.1371/journal .pone. 0059776

Law JLM, Logan M, Wong J, Kundu J, Hockman D, Landi A, Chen C, Crawford K, Wininger M, Johnson J, et al. 2018. Role of the E2 hypervariable region (HVR1) in the immunogenicity of a recombinant hepatitis $C$ virus vaccine. J Virol 92: e02141-17. doi:10.1128/JVI.02141-17

Liang TJ. 2013. Current progress in development of hepatitis C virus vaccines. Nat Med 19: 869-878. doi:10.1038/nm .3183

Liu L, Fisher BE, Dowd KA, Astemborski J, Cox AL, Ray SC. 2010. Acceleration of hepatitis $C$ virus envelope evolution in humans is consistent with progressive humoral immune selection during the transition from acute to chronic infection. J Virol 84: 5067-5077. doi:10.1128/JVI.022 65-09

Logvinoff C, Major ME, Oldach D, Heyward S, Talal A, Balfe P, Feinstone SM, Alter H, Rice CM, McKeating JA. 2004. Neutralizing antibody response during acute and chronic hepatitis C virus infection. Proc Natl Acad Sci 101: 1014910154. doi:10.1073/pnas.0403519101

Major ME, Mihalik K, Puig M, Rehermann B, Nascimbeni M, Rice CM, Feinstone SM. 2002. Previously infected and recovered chimpanzees exhibit rapid responses that control hepatitis $\mathrm{C}$ virus replication upon rechallenge. J Virol 76: 6586-6595. doi:10.1128/JVI.76.13.6586-6595.2002

Major M, Gutfraind A, Shekhtman L, Cui Q, Kachko A, Cotler SJ, Hajarizadeh B, Sacks-Davis R, Page K, Boodram $\mathrm{B}$, et al. 2018. Modeling of patient virus titers suggests that availability of a vaccine could reduce hepatitis $\mathrm{C}$ virus transmission among injecting drug users. Sci Transl Med 10: eaao4496. doi:10.1126/scitranslmed.aao4496

Mankowski MC, Kinchen VJ, Wasilewski LN, Flyak AI, Ray SC, Crowe JE, Bailey JR. 2018. Synergistic anti-HCV broadly neutralizing human monoclonal antibodies with independent mechanisms. Proc Natl Acad Sci 115: E82-E91. doi:10.1073/pnas.1718441115

Martell M, Esteban JI, Quer J, Genesca J, Weiner A, Esteban R, Guardia J, Gomez J. 1992. Hepatitis C virus (HCV) circulates as a population of different but closely related genomes: quasispecies nature of HCV genome distribution. J Virol 66: 3225-3229.

Martin TC, Martin NK, Hickman M, Vickerman P, Page EE, Everett R, Gazzard BG, Nelson M. 2013. Hepatitis C virus reinfection incidence and treatment outcome among HIV-positive MSM. AIDS 27: 2551-2557. doi:10.1097/ QAD.0b013e32836381cc

Martinello M, Grebely J, Petoumenos K, Gane E, Hellard M, Shaw D, Sasadeusz J, Applegate TL, Dore GJ, Matthews GV. 2017. HCV reinfection incidence among individuals treated for recent infection. J Viral Hepat 24: 359-370. doi:10.1111/jvh.12666

Mehta SH, Cox A, Hoover DR, Wang XH, Mao Q, Ray S, Strathdee SA, Vlahov D, Thomas DL. 2002. Protection against persistence of hepatitis C. Lancet 359: 14781483. doi:10.1016/S0140-6736(02)08435-0

Merat SJ, Molenkamp R, Wagner K, Koekkoek SM, van de Berg D, Yasuda E, Bohne M, Claassen YB, Grady BP, Prins M, et al. 2016. Hepatitis C virus broadly neutralizing monoclonal antibodies isolated 25 years after spontaneous clearance. PLoS ONE 11: e0165047. doi:10.1371/jour nal.pone. 0165047

Meuleman P, Bukh J, Verhoye L, Farhoudi A, Vanwolleghem T, Wang RY, Desombere I, Alter H, Purcell RH, LerouxRoels G. 2011. In vivo evaluation of the cross-genotype neutralizing activity of polyclonal antibodies against hepatitis C virus. Hepatology 53: 755-762. doi:10.1002/hep .24171

Micallef JM, Kaldor JM, Dore GJ. 2006. Spontaneous viral clearance following acute hepatitis $\mathrm{C}$ infection: a systematic review of longitudinal studies. J Viral Hepat 13: 3441. doi:10.1111/j.1365-2893.2005.00651.x

Micallef JM, Macdonald V, Jauncey M, Amin J, Rawlinson W, van Beek I, Kaldor JM, White PA, Dore GJ. 2007. High incidence of hepatitis $C$ virus reinfection within a cohort of injecting drug users. J Viral Hepat 14: 413-418. doi:10 $.1111 / \mathrm{j} .1365-2893.2006 .00812 . \mathrm{x}$

Midgard H, Bjoro B, Maeland A, Konopski Z, Kileng H, Damas JK, Paulsen J, Heggelund L, Sandvei PK, Ringstad JO, et al. 2016. Hepatitis C reinfection after sustained virological response. J Hepatol 64: 1020-1026. doi:10 .1016/j.jhep.2016.01.001

Morin TJ, Broering TJ, Leav BA, Blair BM, Rowley KJ, Boucher EN, Wang Y, Cheslock PS, Knauber M, Olsen DB, et al. 2012. Human monoclonal antibody HCV1 effectively prevents and treats HCV infection in chimpanzees. PLoS Pathog 8: e1002895.

Nascimbeni M, Mizukoshi E, Bosmann M, Major ME, Mihalik K, Rice CM, Feinstone SM, Rehermann B. 2003. Kinetics of $\mathrm{CD}^{+}$and $\mathrm{CD} 8^{+}$memory T-cell responses during hepatitis $\mathrm{C}$ virus rechallenge of previously recovered chimpanzees. J Virol 77: 4781-4793. doi:10.1128/JVI .77.8.4781-4793.2003

Osburn WO, Fisher BE, Dowd KA, Urban G, Liu L, Ray SC, Thomas DL, Cox AL. 2010. Spontaneous control of primary hepatitis $C$ virus infection and immunity against persistent reinfection. Gastroenterology 138: 315-324. doi:10.1053/j.gastro.2009.09.017

Osburn WO, Snider AE, Wells BL, Latanich R, Bailey JR, Thomas DL, Cox AL, Ray SC. 2014. Clearance of hepatitis $\mathrm{C}$ infection is associated with the early appearance of broad neutralizing antibody responses. Hepatology 59: 2140-2151. doi:10.1002/hep.27013

Page K, Hahn JA, Evans J, Shiboski S, Lum P, Delwart E, Tobler L, Andrews W, Avanesyan L, Cooper S, et al. 2009. Acute hepatitis $\mathrm{C}$ virus infection in young adult injection drug users: a prospective study of incident infection, resolution, and reinfection. J Infect Dis 200: 1216-1226. doi:10.1086/605947

Park SH, Shin EC, Capone S, Caggiari L, De Re V, Nicosia A, Folgori A, Rehermann B. 2012. Successful vaccination induces multifunctional memory T-cell precursors associated with early control of hepatitis C virus. Gastroenterology 143: 1048-1060.e4. doi:10.1053/j.gastro.2012.06 .005

Pestka JM, Zeisel MB, Blaser E, Schurmann P, Bartosch B, Cosset FL, Patel AH, Meisel H, Baumert J, Viazov S, et al. 2007. Rapid induction of virus-neutralizing antibodies and viral clearance in a single-source outbreak of hepatitis C. Proc Natl Acad Sci 104: 6025-6030. doi:10.1073/pnas .0607026104 
A.L. Cox

Pierce BG, Boucher EN, Piepenbrink KH, Ejemel M, Rapp CA, Thomas WD, Sundberg EJ, Weng Z, Wang Y. 2017. Structure-based design of hepatitis $C$ virus vaccines that elicit neutralizing antibody responses to a conserved epitope. J Virol 91: pii: e01032-17. doi:10.1128/JVI.01032-17

Pineda JA, Núñez-Torres R, Téllez F, Mancebo M, García F, Merchante N, Pérez-Pérez M, Neukam K, Macías J, Real LM. 2015. Hepatitis C virus reinfection after sustained virological response in HIV-infected patients with chronic hepatitis C. J Infect 71: 571-577. doi:10.1016/j.jinf.2015 .07 .006

Polakos NK, Drane D, Cox J, Ng P, Selby MJ, Chien D, O'Hagan DT, Houghton M, Paliard X. 2001. Characterization of hepatitis $\mathrm{C}$ virus core-specific immune responses primed in rhesus macaques by a nonclassical ISCOM vaccine. J Immunol 166: 3589-3598. doi:10.4049/jimmu nol.166.5.3589

Prentoe J, Jensen TB, Meuleman P, Serre SB, Scheel TK, Leroux-Roels G, Gottwein JM, Bukh J. 2011. Hypervariable region 1 differentially impacts viability of hepatitis $\mathrm{C}$ virus strains of genotypes 1 to 6 and impairs virus neutralization. J Virol 85: 2224-2234. doi:10.1128/JVI.0159410

Prince AM. 1994. Immunity in hepatitis C virus infection. Vox Sang 67(Suppl 3): 227-228.

Prince AM, Brotman B, Lee DH, Pfahler W, Tricoche N, Andrus L, Shata MT. 2005. Protection against chronic hepatitis $\mathrm{C}$ virus infection after rechallenge with homologous, but not heterologous, genotypes in a chimpanzee model. J Infect Dis 192: 1701-1709. doi:10.1086/496889

Raghuraman S, Park H, Osburn WO, Winkelstein E, Edlin BR, Rehermann B. 2012. Spontaneous clearance of chronic hepatitis $C$ virus infection is associated with appearance of neutralizing antibodies and reversal of T-cell exhaustion. J Infect Dis 205: 763-771. doi:10.1093/infdis/jir835

Razavi H, Sanchez Y, Pangeri A, Cornberg M. 2019. SAT260-Global timing of hepatitis C virus elimination: estimating the year countries will achieve the World Health Organization elimination targets. J Hepatol 70: e748. doi:10.1016/S0618-8278(19)31493-8

Rehermann B. 2009. Hepatitis C virus versus innate and adaptive immune responses: a tale of coevolution and coexistence. J Clin Invest 119: 1745-1754. doi:10.1172/ JCI39133

Rollier C, Depla E, Drexhage JA, Verschoor EJ, Verstrepen BE, Fatmi A, Brinster C, Fournillier A, Whelan JA, Whelan M, et al. 2004. Control of heterologous hepatitis C virus infection in chimpanzees is associated with the quality of vaccine-induced peripheral T-helper immune response. J Virol 78: 187-196. doi:10.1128/JVI.78.1.187196.2004

Rollier C, Verschoor EJ, Paranhos-Baccala G, Drexhage JA, Verstrepen BE, Berland JL, Himoudi N, Barnfield C, Liljestrom P, Lasarte JJ, et al. 2005. Modulation of vaccineinduced immune responses to hepatitis $\mathrm{C}$ virus in rhesus macaques by altering priming before adenovirus boosting. J Infect Dis 192: 920-929. doi:10.1086/432517

Rollier CS, Paranhos-Baccala G, Verschoor EJ, Verstrepen BE, Drexhage JA, Fagrouch Z, Berland JL, KomurianPradel F, Duverger B, Himoudi N, et al. 2007. Vaccineinduced early control of hepatitis $\mathrm{C}$ virus infection in chimpanzees fails to impact on hepatic PD-1 and chronicity. Hepatology 45: 602-613. doi:10.1002/hep.21573

Sacks-Davis R, Grebely J, Dore GJ, Osburn W, Cox AL, Rice TM, Spelman T, Bruneau J, Prins M, Kim AY, et al. 2015. Hepatitis $\mathrm{C}$ virus reinfection and spontaneous clearance of reinfection-the $\mathrm{InC}^{3}$ study. J Infect Dis 212: 14071419. doi:10.1093/infdis/jiv220

Scherer EM, Smith RA, Simonich CA, Niyonzima N, Carter JJ, Galloway DA. 2014. Characteristics of memory B cells elicited by a highly efficacious HPV vaccine in subjects with no pre-existing immunity. PLoS Pathog 10: e1004461. doi:10.1371/journal.ppat.1004461

Schulkind J, Stephens B, Ahmad F, Johnston L, Hutchinson S, Thain D, Ward Z, Vickerman P, Hickman M, Dillon JF. 2019. High response and re-infection rates among people who inject drugs treated for hepatitis $\mathrm{C}$ in a community needle and syringe programme. J Viral Hepat 26: 519528. doi:10.1111/jvh.13035

Schulze zur Wiesch J, Ciuffreda D, Lewis-Ximenez L, Kasprowicz V, Nolan BE, Streeck H, Aneja J, Reyor LL, Allen TM, Lohse AW, et al. 2012. Broadly directed virus-specific $\mathrm{CD} 4^{+} \mathrm{T}$ cell responses are primed during acute hepatitis $\mathrm{C}$ infection, but rapidly disappear from human blood with viral persistence. J Exp Med 209: 61-75. doi:10.1084/jem .20100388

Scott N, McBryde E, Vickerman P, Martin NK, Stone J, Drummer H, Hellard M. 2015. The role of a hepatitis C virus vaccine: modelling the benefits alongside directacting antiviral treatments. BMC Med 13. doi:10.1186/ s12916-015-0440-2

Shin EC, Park SH, Nascimbeni M, Major M, Caggiari L, de Re V, Feinstone SM, Rice CM, Rehermann B. 2013. The frequency of $\mathrm{CD} 127^{+}$hepatitis $\mathrm{C}$ virus (HCV)-specific T cells but not the expression of exhaustion markers predicts the outcome of acute HCV infection. J Virol 87: 4772-4777. doi:10.1128/JVI.03122-12

Shoukry NH, Grakoui A, Houghton M, Chien DY, Ghrayeb J, Reimann KA, Walker CM. 2003. Memory CD8 ${ }^{+}$T cells are required for protection from persistent hepatitis $\mathrm{C}$ virus infection. J Exp Med 197: 1645-1655. doi:10.1084/ jem.20030239

Smith DB, Bukh J, Kuiken C, Muerhoff AS, Rice CM, Stapleton JT, Simmonds P. 2014. Expanded classification of hepatitis $\mathrm{C}$ virus into 7 genotypes and 67 subtypes: updated criteria and genotype assignment web resource. Hepatology 59: 318-327. doi:10.1002/hep.26744

Smith DB, Meyers G, Bukh J, Gould EA, Monath T, Muerhoff AS, Pletnev A, Rico-Hesse R, Stapleton JT, Simmonds P, et al. 2017. Proposed revision to the taxonomy of the genus Pestivirus, family Flaviviridae. J Gen Virol 98: 2106-2112. doi:10.1099/jgv.0.000873

Stamataki Z, Coates S, Evans MJ, Wininger M, Crawford K, Dong C, Fong YL, Chien D, Abrignani S, Balfe P, et al. 2007. Hepatitis $C$ virus envelope glycoprotein immunization of rodents elicits cross-reactive neutralizing antibodies. Vaccine 25: 7773-7784. doi:10.1016/j.vaccine.2007.08 .053

Stone J, Martin NK, Hickman M, Hellard M, Scott N, McBryde E, Drummer H, Vickerman P. 2016. The potential impact of a hepatitis $\mathrm{C}$ vaccine for people who inject drugs: is a vaccine needed in the age of direct-acting an- 
tivirals? PLoS ONE 11: e0156213. doi:10.1371/journal .pone. 0156213

Swadling L, Capone S, Antrobus RD, Brown A, Richardson R, Newell EW, Halliday J, Kelly C, Bowen D, Fergusson J, et al. 2014. A human vaccine strategy based on chimpanzee adenoviral and MVA vectors that primes, boosts, and sustains functional HCV-specific T cell memory. Sci Transl Med 6: 261ra153. doi:10.1126/scitranslmed .3009185

Thomas E, Liang TJ. 2016. Experimental models of hepatitis $\mathrm{B}$ and $\mathrm{C}-$ new insights and progress. Nat Rev Gastroenterol Hepatol 13: 362-374. doi:10.1038/nrgastro.2016.37

Timm J, Lauer GM, Kavanagh DG, Sheridan I, Kim AY, Lucas M, Pillay T, Ouchi K, Reyor LL, Schulze zur Wiesch J, et al. 2004. CD8 epitope escape and reversion in acute HCV infection. J Exp Med 200: 1593-1604. doi:10.1084/ jem.20041006

van de Laar TJ, Pybus O, Bruisten S, et al. 2009a. Evidence of a large, international network of HCV transmission in HIV-positive men who have sex with men. Gastroenterology 136: 1609-1617. doi:10.1053/j.gastro.2009.02.006

van de Laar TJ, Molenkamp R, van den Berg C, Schinkel J, Beld MG, Prins M, Coutinho RA, Bruisten SM. 2009b. Frequent $\mathrm{HCV}$ reinfection and superinfection in a cohort of injecting drug users in Amsterdam. J Hepatol 51: 667674. doi:10.1016/j.jhep.2009.05.027

Vanwolleghem T, Bukh J, Meuleman P, Desombere I, Meunier JC, Alter H, Purcell RH, Leroux-Roels G. 2008. Polyclonal immunoglobulins from a chronic hepatitis $\mathrm{C}$ virus patient protect human liver-chimeric mice from infection with a homologous hepatitis C virus strain. Hepatology 47: 1846-1855. doi:10.1002/hep.22244

Vietheer PT, Boo I, Gu J, McCaffrey K, Edwards S, Owczarek C, Hardy MP, Fabri L, Center RJ, Poumbourios P, et al. 2017. The core domain of hepatitis $C$ virus glycoprotein E2 generates potent cross-neutralizing antibodies in guinea pigs. Hepatology 65: 1117-1131. doi:10.1002/hep .28989

Villano SA, Vlahov D, Nelson KE, Lyles CM, Cohn S, Thomas DL. 1997. Incidence and risk factors for hepatitis
C among injection drug users in Baltimore, Maryland. J Clin Microbiol 35: 3274-3277.

von Delft A, Donnison TA, Lourenço J, Hutchings C, Mullarkey CE, Brown A, Pybus OG, Klenerman P, Chinnakannan S, Barnes E. 2018. The generation of a simian adenoviral vectored $\mathrm{HCV}$ vaccine encoding genetically conserved gene segments to target multiple HCV genotypes. Vaccine 36: 313-321. doi:10.1016/j.vaccine.2017 .10 .079

Wang C, Liu Y, Cavanagh MM, Le Saux S, Qi Q, Roskin KM, Looney TJ, Lee JY, Dixit V, Dekker CL, et al. 2015. B-cell repertoire responses to varicella-zoster vaccination in human identical twins. Proc Natl Acad Sci 112: 500-505. doi:10.1073/pnas.1415875112

Ward S, Lauer G, Isba R, Walker B, Klenerman P. 2002. Cellular immune responses against hepatitis $\mathrm{C}$ virus: the evidence base 2002. Clin Exp Immunol 128: 195-203.

White B, Madden A, Prins M, Hellard M, Wand H, Dore GJ, Page K, Maher L. 2014. Assessing the feasibility of hepatitis C virus vaccine trials: Results from the Hepatitis C Incidence and Transmission Study-community (HITS-c) vaccine preparedness study. Vaccine 32: 5460-5467. doi:10.1016/j.vaccine.2014.07.091

World Health Organization (WHO). 2016. Human Challenge Trials for Vaccine Development. www.who.int/ biologicals/expert_committee/Human_challenge_Trials_ IK_final.pdf

World Health Organization (WHO). 2017. Global Hepatitis Report. apps.who.int/iris/bitstream/handle/10665/2550 16/9789241565455-eng.pdf?sequence=1

Youn JW, Hu YW, Tricoche N, Pfahler W, Shata MT, Dreux M, Cosset FL, Folgori A, Lee DH, Brotman B, et al. 2008. Evidence for protection against chronic hepatitis $C$ virus infection in chimpanzees by immunization with replicating recombinant vaccinia virus. J Virol 82: 10896-10905. doi:10.1128/JVI.01179-08

Zubkova I, Duan H, Wells F, Mostowski H, Chang E, Pirollo K, Krawczynski K, Lanford R, Major M. 2014. Hepatitis C virus clearance correlates with HLA-DR expression on proliferating $\mathrm{CD}^{+} \mathrm{T}$ cells in immune-primed chimpanzees. Hepatology 59: 803-813. doi:10.1002/hep.26747 


\section{$\&_{\mathrm{CSH}}^{\infty} \&$ Cold Spring Harbor

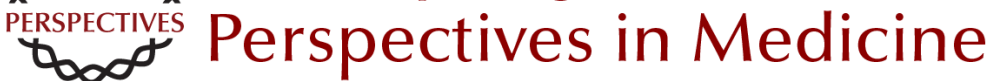

\section{Challenges and Promise of a Hepatitis C Virus Vaccine}

Andrea L. Cox

Cold Spring Harb Perspect Med 2020; doi: 10.1101/cshperspect.a036947 originally published online September 23, 2019

Subject Collection Hepatitis C Virus: The Story of a Scientific and Therapeutic Revolution

Antibody Responses in Hepatitis C Infection Mansun Law

T-Cell Immunity against the Hepatitis C Virus: A Persistent Research Priority in an Era of Highly Effective Therapy

Stephanie Smith, Jonathan R. Honegger and Christopher Walker

Interferon-Free Hepatitis C Virus Therapy Jean-Michel Pawlotsky

Animal Models of Hepatitis C Virus Infection Alexander Ploss and Amit Kapoor

Natural History of Hepatic and Extrahepatic Hepatitis C Virus Diseases and Impact of Interferon-Free HCV Therapy

Francesco Negro

Hepatitis C Virus Epidemiology and the Impact of Interferon-Free Hepatitis C Virus Therapy Jeffrey V. Lazarus, Elena Roel and Ahmed M. Elsharkawy

Hepatitis C Virus Entry: Protein Interactions and Fusion Determinants Governing Productive Hepatocyte Invasion

Gisa Gerold, Rebecca Moeller and Thomas Pietschmann

Hepatitis C Virus Structure: Defined by What It Is Not

Altaira D. Dearborn and Joseph Marcotrigiano
Innate Immunity in Hepatitis C Virus Infection Johannes Schwerk, Amina Negash, Ram Savan, et al.

HCV Assembly and Egress via Modifications in Host Lipid Metabolic Systems Kunitada Shimotohno

Control of HCV Infection by Natural Killer Cells and Macrophages

Hugo R. Rosen and Lucy Golden-Mason

The Elimination of Hepatitis $\mathbf{C}$ as a Public Health

Threat Margaret Hellard, Sophia E. Schroeder, Alisa Pedrana, et al.

Hepatitis C Virus Replication Keisuke Tabata, Christopher J. Neufeldt and Ralf Bartenschlager

Challenges and Promise of a Hepatitis C Virus Vaccine Andrea L. Cox

Rewiring Host Signaling: Hepatitis C Virus in Liver Pathogenesis

Alessia Virzì, Armando Andres Roca Suarez, Thomas F. Baumert, et al.

Hepatitis C Virus: $\mathbf{3 0}$ Years after Its Discovery Michael Houghton

For additional articles in this collection, see http://perspectivesinmedicine.cshlp.org/cgi/collection/ 